\title{
Continuous Wound Infiltration of Local Anesthetics in Postoperative Pain Management: Safety, Efficacy and Current Perspectives [Corrigendum]
}

Paladini G, Di Carlo S, Musella G, et al. J Pain Res. 2020;13:285-294.

On page 289 , line 13 , the sentence "The use of epinephrine added to LAs is not recommended by the authors of this review" should read "The use of epinephrine added to LAs is recommended by the authors of this review".

The authors apologize for this error.

\section{Publish your work in this journal}

The Journal of Pain Research is an international, peer reviewed, open access, online journal that welcomes laboratory and clinical findings in the fields of pain research and the prevention and management of pain Original research, reviews, symposium reports, hypothesis formation and commentaries are all considered for publication. The manuscript management system is completely online and includes a very quick and fair peer-review system, which is all easy to use. Visit http:// www.dovepress.com/testimonials.php to read real quotes from published authors. 